\title{
4 State and violence in Burma/Myanmar
}

\section{The Rohingya crisis and its implication for South and South-East Asia}

\author{
Kazi Fahmida Farzana
}

The 2017 sudden explosion of nearly a million Rohingya refugees from Myanmar to its bordered neighbour Bangladesh took the world by surprise at a time when the decades-old domestic ethnic violence and instability in Myanmar were abating and a time of democratic peace was making inroads in the country through democratic reforms and a slow transition from the authoritarian military rule. The incident brought the entire world into this locality, exposing the multitude and inhuman facades of the decades-old globally and, to a large extent, even regionally, ignored ethnic conflict. As more and more regional and global powers became engaged with the issue, a new look at the dynamic of peace and conflict in the region on the same or similar issues has been warranted from the policymakers, policy groups, and academic investigators.

Myanmar has long been known as a repressive military state. However, it, after five decades of military rule, has, since 2010 , with its apparent change of government from military to civilian, benefitted from positive media, resulting in many North American and European countries lifting their sanctions. Events which have been instrumental include its election in November 2015 and the subsequent so-called 'democratic government' that formed in March 2016, indicating to foreign powers that it is willing to move towards democracy. Among other positive changes, some important ones were a noticeable relaxing of restrictions on freedom of expression, allowing a limited number of political groups to form, and the release of several political prisoners from jail brought hope among the international community that the country has been moving towards democracy.

However, several years on, many still argue that Myanmar is only a quasi-military, as the influence and presence of the military is still very strong within the current elected government (Bünte 2014; Beets 2015; Stokke, Vakulchuk, and Øverland 2018). Indeed, the topmost ranked files are filled by the former military regime, and one-fourth of the seats in both the upper and lower houses of the legislative branch are appointed by the military. A partial list would include senior General Min Aung Hlaing, who is the commander-in-chief of the armed forces who has been referred to by the United Nations as a candidate of 'war criminals' (Fortify Rights 2014), because of the crimes he committed against the Kachin and the Shan. The second-in-command is the home minister, Lt-General Kyaw Swe, who is accused of masterminding the murder of lawyer $\mathrm{U} \mathrm{Ko} \mathrm{Ni,}{ }^{1}$ a prominent member of the Muslim minority and legal advisor to Myanmar's ruling National League 
for Democracy Party. The third-most powerful person is the minister of border affairs, Lt-General Ye Aung, who is responsible for the development of border areas and national races. And last but not least the fourth person in this group is the minister of defence, Lt-General Sein Win, who is responsible for the country's national security and the armed forces.

These facts reveal the military's continued grip on key institutions of power. Together, the four men control the most important state institutions, wielding power to manipulate the political and legal systems, to encourage and patronize xenophobic nationalism among Burmese citizens in favour of the predominant Theravada Buddhists' Burman nationalism, and mobilize ethno-religious prejudices, hatred, and violence on other ethnic and religious minorities that only confirm the repressive authoritarian nature of the state.

Hence, under the current quasi-military government political reforms appear no more than eyewash which is reflective its current human rights record, which is considered to be worse than during the past military era. The past pattern of violence and atrocities against the Shan, Karen, Karenni, and Rohingya ethnic minorities continue with similar and, in some cases, with greater intensity. Even though the apparent democratizing trend has brought Myanmar in closer relations with countries, regionally and globally, the implications of the continued repressive military policies fall primarily on the neighbouring South and South-East Asian countries.

The current chapter analyses the state of violence on the Rohingya ethnic minority group of Myanmar and its possible implications for the neighbouring countries in South and South-East Asian nations. Drawing on primary sources from partial fieldwork (in Bangladesh and Malaysia) involving interviews and focus group discussions with about 200 refugees and secondary sources, the analysis of this chapter argues that the internal ethno-religious conflicts in Myanmar have spillover effects on the neighbouring countries as the persecuted Rohingya community has largely dispersed in those countries like Bangladesh, India, Malaysia and Indonesia. The economic and social pressures of the displaced Rohingyas are likely to generate interstate diplomatic and socio-political tension between those countries and Myanmar.

\section{Theoretical framework}

The central problem of the Rohingya is that they claim their citizenship to the country as their natural right, but the state political authority continues to deny this natural right and entitlement, claiming that the Rohingya are outsiders or illegal immigrants. The question about the identity of the Rohingya of Myanmar can be discussed from the perspectives of the multiculturalism theory.

Over the past few decades, there is a changing political trend in Western democracies, strengthening cultural, minority and ethnic prominence in politics. According to Kymlicka, there are "shifts away from historic policies of assimilation or exclusion towards a more 'multicultural' approach that recognizes and accommodates diversity" (2005: 28). It focuses on the micro features and diversities in the society, giving rise to the theory of multiculturalism (Kymlicka 1995). 
The multicultural theorists argue that the conventional perception of citizenship rights was originally developed and defined by white men and for white men (Marshall 1965). So, such a concept is unable to accommodate the particular feeling, perceptions and needs of non-white or minority groups.

The theory of multiculturalism visualizes social equality within a larger common identity, through differentiated recognition, rather than merging differences. Kymlicka (1995) argued that "[a] comprehensive theory of justice in a multicultural state will include both universal rights, assigned to individuals regardless of group membership. And certain group differentiated rights or 'special status' for minority cultures" (6). This is because, as Young $(1989,1990)$ argued, group differences are fundamental and natural; therefore, any attempt to develop a universal conception of citizenship overlooking the group differences would be unjust to the groups.

Kymlicka (1995) has identified four mechanisms that fall under the boundary of multiculturalism. Those are known as assimilation, integration, accommodation and ethno-federalism. Assimilation refers to the government policy to compel the minority groups to abandon their cultural peculiarities and adopt those of the majority group. This policy strikes on the identity of the group rather than forcing the group out of the territory. If the group's cultural characteristics were eliminated, then their identity would be assimilated into the dominant group. For instance, the Canadian policy, in the early twentieth century, to forcefully segregate aboriginal children from their parents, forcing them to live in boarding schools, was implemented to forcefully re-socialize them out of the aboriginal cultural influences. The second mechanism is integration, which involves a greater amount of willingness on both majority and minority groups to recognize each other's privileges and existence in exchange for certain compromises. Here, the minority recognizes and accepts that the majority will be culturally privileged, and will have larger control on resources and decision-making; in exchange, the majority will recognize and accept the minority's right to practice and maintain aspects of its culture. The Malaysian experience in letting the Chinese and Indian communities continue to use their respective languages in schools or in maintaining their vernacular and culture-specific schools are examples of the integration mechanism.

The third multicultural mechanism is called accommodation, which prescribes a higher degree of cultural freedom for the minority. Known also as cultural autonomy or affirmative action policies or "special representation rights" (Kymlicka 1995: 7), the accommodation mechanism ensures extensive rights and privileges reserved for members of minority ethnic groups. The policy may offer a range of greater rights such as the right to attend schools where the curriculum is designed in the minority language, special treatment in hiring, quotas for certain government positions and preference to minority members. The affirmative action policies of the United States exemplify the mechanism of accommodation. A much improved and institutional version of accommodation is known as "consociational democracy" (Ahmen 2005: 27) practised in the Netherlands. And finally, the ethno-federalism policy, which confers, on the minority groups, territorial autonomy with a high degree of, but not complete control over, resources 
and decision-making. Only specific powers are delegated to the groups to manage regional governance specific to the region and the groups; an entire country could be a federation of ethnic autonomous territories. In this case, the ethnic minorities must be geographically concentrated in particular regions in ways that the regions can be clearly distinguishable from each other. Known also as "self-government rights" (Kymlicka 1995: 7), such as the reservation system of the American Indians, the demand for group rights is not seen as a temporary measure; rather, such rights are natural. Aboriginal peoples and other national minorities such as the Quebecois or Scots claim permanent and inherent rights, grounded in a principle of self-determination. These groups occupy a particular homeland or territory and share a distinct language, culture, heritage and history. Such cultural nations are usually located within the territories of a larger and different political community but claim, due to their distinctiveness, the right to self-autonomy to maintain their distinct culture and otherness. What these national minorities want is not primarily better representation in the central government but, rather, the transfer of power and legislative jurisdictions from the central government to their own communities. The Belgian, Canadian and the autonomous regions of China are examples of ethno-federalism.

The theory of multiculturalism and the various mechanisms are based on recognizing differences; hence, known also as "differentiated citizenship" and "multicultural citizenship" in contrast to the universal citizenship. Although the theory is West-centric, we have seen some Asian countries such as China and Malaysia adopted various forms of multiculturalism. It apparently looks more attractive for multi-ethnic nations, in situations where integration, or common culture theory of citizenship, was found to be inadequate in resolving issues of sub-national identities.

\section{The facts about the state of violence on the Rohingya}

The Rohingya are a historical ethnic minority Muslim population in the state of Rakhain in Myanmar. Historically, Rakhain is known as Arakan, which was an independent kingdom during the Mughal Empire and until the advance of the British colonialism in the region. Once Burma became a part of the British India border, re-organization placed Arakan in the Burmese administrative region, but it maintained certain autonomous status. However, upon the Burmese independence in 1948, the Burmese government adopted a fierce nationalist agenda of unification and homogenization which caused ethno-nationalist separatist movements in a number of regions among which Arakan was one. However, compared with other ethnic groups in Myanmar, the Arakani Muslims experienced more systematic and sustained forms of persecution apparently on three grounds: that they collaborated with the British Army to fight against the Burmese, that some of them were Indian labourers who were brought to Arakan during the British period and therefore were not deemed as ethnic to the land and that they were Muslims. To maintain an absolute grip on the region, the Burmese government applied systematic exclusion methods such as denying citizenship to the Rohingyas, imposing social, economic, political and religious restrictions, and forceful eviction and 
expulsion. Simultaneously, the government adopted human transplantation in the region by the local Buddhist in an attempt to create severe population imbalance against the Muslims to the point of their extinction.

A classical method of persecution that any military or authoritarian regime employs in wartime or ethnic cleansing cases, such as what happened during the Japanese occupation of China and South Korea during World War II and the Serbian ethnic cleansing of the Bosnian Muslims in the Balkans in the 1990s (Chang 1997; Tanaka 2001; Skjelsbæk 2011; Hirschauer 2014) is sexual violence in the form of rape and mutilation. The Myanmar military regime applied the same method of sexual violence on the Rohingya women systematically for decades. My fieldwork and personal interviews in February 2018 with survivors who had fled to Bangladesh and Malaysia revealed numerous instances of gang rape and cruel violence by Myanmar's military and security forces. Reports by various rights groups and aid organizations also shed light on rape being used as a key component of the military's persecution of the Rohingya to force them out of the country (Bennett 2017). Pramila Patten, United Nations' special rapporteur on sexual violence in conflict, has been noted as saying, "Sexual violence is being commanded, orchestrated and perpetrated by the Armed Forces of Myanmar" (Quadir 2017: 89). The 2017 Human Rights Watch report interviewed 52 women from 19 different villages of the Rakhine state and found that 29 had been raped. Skye Wheeler, a Human Rights Watch researcher, said:

Rape has been used by the armed forces of Myanmar as one of the ways to carry out ethnic cleansing. It worked out so effective to attack someone, because rape often has lasting traumatic memories that make it even harder for women to go back to Myanmar and feel safe in places where they have been assaulted.

(Hancock 2017)

The available numerous authentic documents testify that for decades the Rohingya have undergone systematic denial to legitimate rights, and persecution of arson, torture, arbitrary killing, gang rape, being burnt alive, forceful detention and other grave human rights violations by Myanmar military and state security as well as civilian forces (Selth 2018). The United Nations has termed this a "textbook example of ethnic cleansing" (UN News 2017) while others have called this a "slow genocide" (Ibrahim 2016; Klug 2018). As a consequence of these multiple forms of perpetrated violence nearly 2 million Rohingya Muslims have fled Myanmar since the late 1970s (Farzana 2017). Many took shelter in neighbouring South Asian countries (Bangladesh, India), South-East Asian countries (Malaysia, Thailand, Indonesia) and beyond.

Of these countries, Bangladesh being the bordering state with Rakhain, it bears the heaviest burden of the fleeing Rohingya population. Bangladesh is currently a host to over a million Rohingya refugees. According to a United Nations High Commissioner for Refugees (UNHCR 2018) report, following an escalation in violence in Rakhine, between August 2017 and 31 July 2018, approximately 723,527 Rohingya population were forced to leave the Rakhine state of Myanmar 
and entered into Bangladesh. This makes it the third-largest recorded exodus of the Rohingya; the first and second forced migrations were in 1978 during Operation Nagamin (Dragon King) and in 1991 during the Pyi Thaya (Prosperous Country) Operation. Other than Bangladesh, India also has sizeable number of Rohingya refugees. Indian prime minister's plan to send an estimated 56,500 Rohingya refugees currently in India to Bangladesh caused tensions between the countries.

Among the South-East Asian countries, Thailand and Indonesia have been used as a transit point by the refugees to enter into Malaysia. Perhaps that is why the number of Rohingya refugees in Thailand is small, which is about 5,000, and Indonesia has about 1,750 Rohingya refugees mostly concentrated in various camps in Banda Aceh. Malaysia hosts the highest number of Rohingya refugees. As of February 2020, there are 101,010 stateless Rohingya registered with the UNHCR, and an estimated 30,000-plus remain undocumented. Rohingya refugees in Thailand, Indonesia and Malaysia are a very underprivileged, marginalized social group facing constant challenges, and their marginal status has been exacerbated by various local socio-political factors/circumstances. During our interviews with the Rohingya refugees in Malaysia, most of them mentioned 'fear of detention' by saying things like "sufferings greet us all the time", "no respect for Rohingya" and "police and immigration officers search for us". This situation is connected to the state attitude and policies towards the refugees. None of these countries is a signatory to the 1951 UN Refugee Convention or its Protocol and, therefore, are not bound to have any legal framework or protection mechanism for refugees. Registered refugees are not documented migrants and all are considered 'illegal', 'prohibited' immigrants and 'security threat' under the law.

Forceful internal and cross-border displacement and expulsion of a large number of people as refugees being an obvious consequence of the state repression, there are also unintended inhuman consequences for countries like Bangladesh, India, Indonesia and Malaysia, Thailand and other parts of the world as many of the persecuted people would take illegal routes for escape, therefore leading to human trafficking, social insecurity and further new challenges to human security in those countries.

The case of Rohingya can be explained from the perspective of 'Structural Violence', a situation purportedly created by an authority through state institutions and policies targeting a particular group of people with an intention to inflict a predesigned consequence on them. Obviously, the most direct of that structural violence is the Rohingya people being 'stateless' despite their having a legitimate state. This statelessness is something that is produced by their own state and not created by the people or the community itself. It is an imposed condition by the state with stated intention. Once a community is made stateless, it becomes legally and structurally subject to all and any form of depravation and violence. The depriving state in such a situation institutionalizes its acts through legal regimes and political socialization of its people that its acts and policies are legitimate. According to Maung Zarni (2017), stateless is structural violence, and structural inequality and structural violence are connected. He further argues that statelessness is structural violence which is linked to political socialization or domestic societal tendency and an illiberal regime miseducates its citizens 
about the concept of what people or communities are. The state may mobilize ethno-religious prejudices and, in some cases, hatred to advance its political agenda (Zarni 2017). Desmond Tutu has rightly commented that such "discrimination doesn't come naturally; it is taught" (quoted in Zhou and Safi 2017).

\section{The Myanmar state narratives: politics of labelling}

Like every state that practices such policies, Myanmar has its own narrative of justification of its acts and policies towards the Rohingya people which is based on puritanical nationalism. This form of nationalism is inclusive of its ethno-religious and cultural-linguistic homogeneity, on one hand, and simultaneously exclusive of non-conforming others, on the other hand. As such, the dominant narrative of the Myanmar government has been focused on rejecting the Rohingya by denying them their legality, personalities, and citizenship. The dominant narratives of the state and state-centred history claim that in the post-independent Rakhine state, all Rohingya Muslims are illegal immigrants. It has constructed and framed the Rohingya minority as "Other", hence justifying the state's actions in eliminating "the existential threat" to the Burmese population and its way of life (Holt 2019).

In constructing as well as maintaining its grand narrative, the Myanmar government has always rejected all accusations against its military and government of the ethnic cleansing that has been taking place in the Rakhine state. Although Aung Sun Suu Kyi promised that "Myanmar will ensure secure environment for all communities" (Ranjan 2017: 2), there are clear indications that the nationalist, quasi-military government views the Rohingya as an "illegal insurgent group," not as citizens.

The grand narrative is constructed carefully by playing with the historical records through a combination of distortion, rewriting and omitting of the historical facts with regard to Arakan and its people. This process started mainly after the conquest of Arakan by the Burman in 1784. Between 1784 and 1948, Arakan witnessed a long tussle between the British Indian and the Burmese kingdom over its territory as the British Indian authority wanted to use it as a buffer zone to prevent the Burmese threat, and the Burmese authority wanted to take complete control over the land to push the British threat farther west. Thus, the official grand narrative claims that the people in the land were artificially planted by the British authority for its advantage and those people came from the British Bengal. Therefore, the Arakani Muslims are not native to the land, and they do not naturally form a part of the Burmese nationhood. Since, according to the Burmese claim, this is the historical facts about the people of Arakan, they are outsiders and therefore do not qualify for citizenship. So the policies of exclusion are not discriminatory; rather, these are legally justified.

While this grand narrative has some merits, it hides many other historical realities and facts that suggest an otherwise narrative. Other available authentic historical sources suggest that the politics over the land, locality, people and their identity of the region is much more complicated than its simplified version presented by the Burmese authority. A cursory look at the major historical facts present with the following scenario. 
First, the area between modern Burma and Bangladesh, where today's Rakhine state is located, has a long history of people travelling or moving back and forth across the boundary. Rakhine was once an independent Maruk-U (the ancient name of Arakan) kingdom, separated from the two Burmese kingdoms in Central Burma and the Irrawaddy Delta, as well as Bengal and the Mogul Empires in India (Charney 2016). In 1459 CE, the Arakani kingdom conquered the adjacent Chittagong region on its western frontier (today's south-eastern part of Bangladesh) and ruled it until $1666 \mathrm{CE}$. Evidence from Arakan genealogy demonstrates that during this time, the Muslims' relationship with the Maruk-U kingdom became stronger, which also explains the Bengali influence in Arakan. Some of the Arakanese kings even adopted Muslim names (Phayre 1967; Jilani 1999), and "became somewhat Mahomedanised in their ideas" (Bhattacharya 1927: 141). During this time, "an attitude of tolerance prevailed, with Theravada and Mahayana Buddhism, together with Brahmanism, Hinduism, animism and other beliefs" (Blackburn 2000: 14). Thus, it was an inclusive and heterogeneous society that tolerated each other.

Second, historically, it appears that the ethnic tensions were deeply rooted even before modern Burma as a nation came into being. Conflict in Arakan can be traced to the late fourteenth and early fifteenth centuries, when various invasions came from the Irrawaddy Valley, from the Kingdom of Ava and the Kingdom of Pegu, which, at the time, were engaged in a massive war with each other (Charney 2016). Subsequently, in 1784, the Burmese king Bodawpaya conquered and incorporated the Arakan region into his kingdom, Ava, in Central Burma. During this incorporation process, the king replaced the Arakan throne with their own kings and brought in administrators, soldiers and settlers. This transformation of integration with the Irrawaddy Valley brought about in this region the Irrawaddy Valley culture, the Burmese language, Burmese script, Theravada Buddhist monks and Theravada Buddhism that first appeared as a royal cult in Arakan (Charney 2016).

During this period a systematic socio-political and economic oppression was inflicted on the people of Arakan by the Burman king. The most common form of oppression was heavy taxation imposed on the people. G. E. Harvey (1967: 280) mentioned that those who were not able to pay taxes were summoned to various garrison headquarters, and "when they arrived the Burmese would round them up and massacre them." Many similar incidents were reported with thousands of people (both Muslim and Buddhist Rakhines) killed between 1790 and 1797, compelling thousands more to flee from this area to the then adjoining British colonial territory of Bengal (Harvey 1967: 282). The local Arakanese began to rebel against the Burmese oppression. Thus, it can be argued that Arakan was deeply affected by the invasion of the Irrawaddy Valley. Since then, the relationship between the state of Arakan and the Burmese king was marked by animosity and deep mistrust.

Third, another murky episode that deepened the enmity between the local people and the Burmese kings was when the British imperial power colonized Burma (1824-1886). Their first step was to annex Arakan and use it as a buffer zone to invade mainland Burma. Faced with severe oppression by the Burmese 
king, the Arakanese supported the British when the colonizers offered their support. During this time, as part of the British dual administration policy, the ethnic minority-based frontier areas and other ethnic and religious groups were able to move to the top levels of the colonial services (Smith 1999), and the peripheral states were allowed to govern their area under the control of traditional rulers. During this time, Arakanese Muslims, Karen, Shan and many other minority groups collaborated with the British colonial power against the Burmese state.

This policy of divide and rule of the British authority comprising ethnic minorities to suppress Burmese resistance (Moscotti 1977) created more a tense and conflictual relationship between the Burmese and ethnic minorities. This was a significant factor in solidifying the boundaries between the Burmese and ethnic minorities. This evolving nature of borderlands' geography has played an important role in constructing, reshaping and complicating the Rohingya identity in the post-independence era.

It is due to these historical facts that the post-independence Burmese government has perceived the Rohingya as collaborators with the British enemy, and since it was the British who brought a large number of Indian labourers to Arakan, the Rohingya were not deemed compatible with the push to promote a sense of national solidarity. Moreover, because their religion, Islam, differed from the dominant practice of Theravada Buddhism, it was easy for the government officials to view and represent them as 'others'. As part of its nation-building process, Burma/Myanmar, under its five decades of military rule until today, has been trying to establish an imaginary nation that is 'homogeneous and exclusivist' so that the majority Theravada Buddhist, Burmese-speaking, Burman culture remain unchallenged.

It is this process of nation building and Burmanization of the land that the politics of 'remaking of Rakhine' (Charney 2016) as part of a greater Myanmar that continues today. By changing its name from Arakan to Rakhine state (named for the majority Buddhist community), militarizing the state, patronizing the in-migration of Rakhine population from various areas to the Rakhine state, making Rakhine look increasingly like the majority culture, language and religion the process of exclusion continues. The process has involved a distortion of the historical facts that the "archaeological sites, texts, and other sources are being remade or expunged to develop a historical record that emphasizes an unchallenged culture and religious homogeneity to the region" (Charney 2016: 4). A recent example of such distortion is that the Myanmar government even officially banned the term Rohingya, claiming that it is a recent invention by Muslim separatists. Aung Sun Suu Kye in her defence of Myanmar at The Hague International Court of Justice did not use the term Rohingya at all. While apart from eight hundred years of the claims of the people, some documents by the Western authors suggest that at least three hundred years earlier, the people used to call themselves Rohingya. Francis Buchanan's diary, published in 1799, mentioned "the Mohammedans, who have long settled in Arakan . . . call themselves Rooinga, or natives of Arakan" (Buchanan 1799: 220). Any attempt to dismiss this kind of evidence will only obscure the truth. The government's denial of history has positively eased Rakhine's integration into the Myanmar nation-state 
but has simultaneously undermined the true Rakhine past, its unique culture and history based on tolerance, inclusion and diversity.

\section{Implications for South and South-East Asian countries}

It is argued in this chapter that in the context of normalizing relations between Myanmar and its South and South-East Asian nations, the conflict between Myanmar authority and the Rohingya ethnic minority community has a spillover effect on Myanmar's neighbours. This is obvious due to voluntary, forceful, or otherwise, refugee flow to the neighbouring countries, the induced diplomatic tensions, and socio-economic and human security-related pressures caused in those countries. The most likely enduring implication could be that the conflict might take a perpetuating tendency due to Myanmar's deliberate state policy of denial of citizenship to the Rohingya minority group considering them as illegal immigrants. The resultant chain implication of this on the neighbouring countries could be that they might to carry the burden of the refugees forever. This will likely compromise with peace in the entire two regions due to socio-economic pressures and human security issues caused by the refugees, cross-border human trafficking, and intentional terrorism and crimes. This a serious contextual analysis.

\section{Bangladesh}

Bangladesh, being the immediate bordering state with Rakhain, faces the horrible nightmare of the refugee pressure. Since Bangladesh had been burdened with a huge number of refugees since the 1978 influx, its initial reaction to the 2017 new influx was to 'push back', yet it failed to control and eventually opened its border due to the gravity of the situation and on humanitarian context. Unwillingly, Bangladesh is now hosting at least 1 million documented Rohingya refugees. The Bangladeshi government maintains that the Rohingyas were not originally from Bangladesh and were not officially known until 1978 when they first crossed the border from Myanmar in huge numbers because of political upheaval in their land of origin.

Hence, the Bangladeshi government views the issue as created by the Myanmar state and reiterates that it is not the ultimate responsibility of Bangladesh to take care of these people and that since the Rohingyas originated from Myanmar, they must return to Myanmar and cannot be allowed to stay in Bangladesh permanently. Under such a resolute denial, the Rohingya refugees in Bangladesh live a miserable life, especially the newcomers. It is a serious humanitarian situation in the Cox's Bazar district of Bangladesh where the refugees have been placed, with some human rights organizations warning that an epidemic may break out at any time, due to the serious lack of food and medical care (Banerjee 2019).

More than a million unwanted refugees have already caused social antagonism in the locality in Bangladesh as the local poor feel that they are deprived of the lucrative foreign food aid handed to the refugees, the local labour market is illegally encroached by the refugees and the inadequate health care facilities for 
the locals are being overpopulated by the refugees. The refugees also cause local political tension as well since political parties and their local interest groups take illegal advantage of the refugees as potential vote bank in exchange of monetary benefits extended to the latter. There is a possibility that this situation may escalate to even more conflicts between refugees and the locals.

To avoid any local or inter-state conflict the Bangladesh government has always maintained its position to solve the crisis through peaceful means of negotiation and full repatriation of the refugees. However, due to deliberate negligence and procrastination on the part of Myanmar, the issue remained unresolved for decades. As late as 23 November 2017, Bangladesh signed a memorandum of understanding (MOU) with Myanmar government (Reuters 2017) on repatriation. The MOU carefully avoided identifying the refugees as 'refugees' or 'Rohingya', instead calling them as 'displaced persons from Rakhine State'. Furthermore, it is fairly obvious that the MOU itself is quite ineffective since it resulted from a hurried expectation on the Bangladesh side of stopping further refugee flow and quickly returning the refugees and, on Myanmar's side, from a tendency to abate the international pressure and criticism.

This fact is very much clear from the terms and conditions of this new agreement of repatriation that these are the same as those of the 1990s repatriation deal (Abrar 1994) - which was mostly a failed attempt - under which refugees had to prove, through documentation, that they were from the Rakhine state and that they had to agree to repatriation on "temporary resident" status. Because both countries do not seem to take the agreements seriously, it is not surprising that refugees continued to rush into Bangladesh until today, although in lesser numbers.

From the refugees' perspective, the repatriation deal is also impractical and seriously objectionable. The refugees in the new settlement sites are still very traumatized by the violence and atrocities they experienced in Myanmar. More than 60 per cent of the new arrivals are women and children (UN Children's Fund 2017). Apparently, the recent violence created many households to be headed by single mothers with lots of orphans. Our fieldwork data from the interviewees in Cox's Bazar in February 2018 documented testimonies that although they had been in Bangladesh for more than six months, the spiralling smoke from their burning villages and the smell of burnt dead bodies still remained painfully fresh in their subconscious minds, creating sleeplessness and a distaste for food.

A more serious concern of any voluntary repatriation on behalf of the refugees is safety and dignity. ${ }^{2}$ The refugees claim that returning to Myanmar without proper assurance of safety and dignity is tantamount to jumping from the frying pan into the fire. This is because the past experience of the refugees who returned earlier faced even more harsh torture and persecution which made many to flee again. This is substantiated by the Amnesty International (2018) report that Myanmar was further militarizing Rohingya villages and eradicating the evidence of their crimes against humanity by bulldozing Rohingya villages and replacing with newly constructed military bases. Furthermore, about five thousand Rohingya remain trapped at no-man's land between Bangladesh and Myanmar (Alsaafin 2018). Several media report also stated that the sound of open 
gunfire and announcements by the Myanmar military were in place to frighten the Rohingya to flee Myanmar (Myint 2019).

Under such a militarized and militant atmosphere in Rakhain, it is inconceivable for the refugees to even think of returning. From their practical experience and observation, the refugees started coming out to be recognized as a party to any repatriation agreement as they on 19 January 2018 submitted a thirteen-point demand to Ms. Yanghee Lee, UN special rapporteur on the human rights situation in Myanmar who visited refugee camps and settlements in Cox's Bazar. The demands included the following seven major points:

1. "citizenship" and equal rights are granted to the Rohingya;

2. a nationality card is issued to them prior to repatriation;

3. the Myanmar government ensures improved law and order for all Rohingya;

4. the UN and ICC are involved in this repatriation process;

5. their original land in the Arakan (Rakhaine) state is returned to them;

6. ICC ensures justice against crimes of gang rape, killing, and destruction of properties; and,

7. the UN fact-finding missions and the investigation teams are allowed to investigate the details arising from the August 2017 incidents.

Not being a signatory to the 1951 Refugee Convention and its 1967 protocol, Bangladesh can officially proceed with the repatriation process. However, any repatriation under the current situation is likely to be a violation of the principle of non-refoulement policy of those relevant conventions that state that refugees should not be forced to return to their home country. This makes the situation even more precarious for Bangladesh in terms of looking after the survival and welfare of the refugees and maintaining local law and order and economic and social stability in the region.

\section{Rivalry between regional powers}

The Rohingya crisis is more than just about Myanmar's religious and ethnic tensions. It has crossed that threshold and has become an international issue. In this connection, it is important to consider major power politics, particularly the two rising powers - China and India. The Arakan/Rakhain issue can potentially cause further regional conflict involving those great as well as regional powers. Myanmar is resource-rich, and it is strategically located near major Indian Ocean shipping lanes. Myanmar has a 2,129-km border with China on the north-east and a 1,468-km border with India on the north-west. Because of its geostrategic importance along with being economically important to both China and India, these countries want to protect and defend their respective interest in Myanmar, with which they have long-established economic and military relations. Both countries have concluded major trade agreements (Zhao 2008; Solanki 2018; Peng 2019). And furthermore, Arakan/Rakhain, being a resourceful region and located on the Indian Ocean shore, has the strategic importance of the region is more lucrative to both China and India. According to many reports, China wants 
to build an Asian highway with a new seaport through Rakhine state in the Bay of Bengal (Kamal 2017). This highway will connect China to the Indian Ocean securing a number of advantages for the country. First, China is unlikely to be comfortable with an increasing American influence in Myanmar as it progresses towards democracy. So a highway directly connecting to the Indian Ocean can substantially counter the strategic influence of the US on Myanmar. Second, with American influence in the South China Sea, China would like to find an alternative route on the proposed Asian highway for its trade and import of oil, bypassing the South China Sea. The highway can also offer China an easy short-cut access to the Indian Ocean to trade with Africa and Europe. Therefore, it is quite logical for China to see the Rakhain region remain free of conflict and security threats from any separatist or insurgent or 'Islamic' terrorist group. Even if this can be ensured by forceful eviction of the entire suspect population, China may maintain no reservation on that. Indeed, this was reflected in the UN Security Council's first meeting on the Rohingya issue on 28 September 2017, when China and Russia supported the Myanmar government. It is to be noted here that both China and Russia are major suppliers of military arms and gadgets to Myanmar.

With regard to India's interest in Myanmar, it maintains a similar perspective like that of China. This is clearly indicated in its official position in support of Myanmar during Prime Minister Narendra Modi's visit in 2018 at a time when the entire world was still horrified by the 2017 Rohingya refugee explosion and Myanmar was heavily criticized for its brutal military atrocities in Rakhain. This opens two opportunities for India. On one hand, it can improve its economic relations with China by joining the Asian highway project to create an economic 'industrial zone' in Myanmar, particularly in the Rakhine state, to exploit its natural resources. On the other, it legitimizes India's plan to send an estimated 56,500 Rohingya refugees currently in India to Bangladesh arguing that they are in fact Bangladeshis. Furthermore, Indian support for Myanmar's expulsion of Rohingyas allegedly being Bangladeshis extends legitimacy to India to expel in a similar fashion the alleged Bengalis from Bangladesh who have been staying illegally in the north-eastern states of India. Such a move has later actually been taken through several censuses in the eastern provinces of India which classified a few million people as non-citizens. On the same issue, India-Bangladesh relations have been tense during 2018-2019.

Clearly, if such a situation persists involving great and regional powers' contestation over the strategic importance of the Rakhain region, then it is likely that their support would make Myanmar invincible in continuing its repression of the Rohingya people and in shrugging off international pressure to accept any responsibility and liability to the expelled millions.

\section{Militancy, extremism and terrorism}

It is a worldwide trend in the contemporary world to label anti-government groups, more specifically separatist groups or movement for independence, as terrorists. Terrorism as a blanket term has effectively criminalized any legitimate activities or movements for self-independence. This is more conveniently used 
against any Muslim group. Countries, where there are large Muslim minority communities concentrated in a specific land area and are active for their autonomy or independence, are subject to such terrorist label. Examples include China (Uighur), India (Kashmir), Myanmar (Rohingyas), Moros (Mindanao, the Philippines), and Turkey (Kurds). Myanmar, in its 2017 large-scale operation against the Rohingya Muslims, officially used the rhetoric of Muslim terrorism. Concurrently, Bangladesh and India also directly stated their official position on concerns of 'national security threat', 'extremism' and 'terrorism' emanating from the 2017 Rohingya expulsion case. On this, Bangladesh sided with the extreme communal Hindu Indian and extremist Buddhist Myanmar governments in identifying the Rohingya as a common 'national security threat'.

The official narratives of labelling the Rohingya refugees as terrorists and extremists are also reinforced by government-linked or even independent think tanks, policy experts and security analysts and experts whose voluminous works over the past few decades, and especially after $9 / 11$, have turned 'Islamic terrorism' a growth industry (Jackson 2007). The international media coverage in support of such views, as well as opinion-making, has also aided in the growth of this industry (El-Aswad 2013).

The downside of this labelling politics is an exoneration of governments and institutions that perpetrate unjust violence, cruelty, oppression, ethnic cleansing and religio-cultural genocide from liability and accountability. The labelling politics rather works as an easy excuse for some countries and leaders to become more oppressive with a free hand. Such indiscriminate and purported labelling can also potentially turn a peaceful community or movement into militancy out of anger, frustration, and desperateness. Many argue that such is the case with the Rohingya community who have been largely peaceful in their approach and claim to political rights, human rights, and natural justice. There are some negligible groups of people who have called for independence of the region, but they remained peaceful until 2017 systematic military atrocities on the Rohingya people to evacuate them and apparently to clear the land for foreign investors. This is arguably true because the Myanmar government claimed that its large-scale operation in 2017 was a follow-up response to the Arakan Rohingya Salvation Army (ARSA) assault on its soldiers. This means ARSA might not have been a militant group earlier until it felt the government atrocities unbearable.

A second and more dangerous implication of Rakhain instability is the refugee flow to other nearby and safer destinations, such as Thailand, Indonesia and Malaysia, and its resultant socio-political consequences. The Indian government and people have shown an intolerant and hostile attitude towards the Rohingya living in the country, with the threat of pushing them back to Bangladesh and labelling them as Bengalis. Such an attitude easily gets mixed with the communal and violent local political trends raising inter-state and regional tension. Following the 2017 mass eviction, Malaysia became the strongest political critic of Myanmar (both Malaysia and Myanmar are Association of South-East Asian Nations [ASEAN] members) going beyond the ASEAN charter of non-interference. Mammoth political rallies headed by the then prime minister and other high-ranking government and political leaders strongly condemned Myanmar's government and the civilian leader Aung Sun Suu Kyi. The Muslim population of 
Malaysia became highly charged and emotional calling for boycotting Myanmar politically and economically (Naidu 2017). In response, the extremist Buddhist people in Myanmar reacted strongly through street demonstrations and burning the national flag of Malaysia (The Bangkok Post 2017). A similar reaction was recorded from the Indonesian side where an increasing number of Rohingya were arriving on a daily basis and many more were floating on the nearby seas. The implication of the incident of Rohingya eviction in 2017 even seriously affected the subsequent ASEAN summit that failed to bring the issue on its agenda displeasing Malaysia. The ASEAN members were seriously divided, and some of them were highly angered. ASEAN, the most cooperative, peaceful, and well-functioning regional organization, became nearly dysfunctional.

A third serious implication for the refugee-hosting countries is socio-economic tension that the refugees create locally as illegal migrants. Because they are considered illegal, they enjoy no legitimate and legal rights to work or education and health care facilities. And yet they need to maintain their daily subsistence. Other than Bangladesh, Rohingya refugees in India, Malaysia, and Indonesia remain largely dispersed in the open society. These people immediately start invading the labour and illegal petty business sectors as a substitute shadow economy. This creates tension among the local population. It is alleged that in Bangladesh and Malaysia, the illegal migrants are often employed by the exploitative production and business sectors with low and sometimes no wages. The corrupt police administration runs a profitable arrest-and-release business in exchange for bribes, and the refugees become a regular issue of electoral politics in those countries.

And the most enduring and inhuman implication for those neighbouring and other distant countries is illegal human trafficking (Human Rights Watch 2015; Menon 2015; Hindustan Times 2017). Due to military and civilian atrocities in Rakhine, the Rohingya people have been taking every possible opportunity to escape to a safer destination out of desperateness. Because legal means of travel is impossible for them, they fall prey to the cruel underground local and international human trafficking networks. It is reported that even the Myanmar Buddhist monks are involved in such trafficking businesses to reap economic benefits from the oppressed and evicting in the process. A clear chain of networks of such underground traffickers was evident when 139 mass graves of Rohingya were uncovered along the Thai-Malaysia border (Yi 2015). On either side of the border, the discovery of a number of mass graves shocked the nations in the region and created a serious political sensation. Indeed, the fieldwork data testify that most of the Rohingya migrants in Malaysia had arrived in the country through underground trafficking. The collateral torture, suffering, and abuse that the moving illegal migrants experience are incredible, particularly the women and children who frequently become victims of rape and end working in prostitution run by criminal rackets.

\section{Conclusion}

As mentioned in the theoretical framework, a democratic nation today is multinational, multi-ethnic, multireligious, multicultural, and multi-linguistic. Such a nation is, by default, a tolerating and coexisting nation with its diversity 
and heterogeneity. The underlying principle is equality and universal citizenship. Such a civic state comes fully in terms with the democratic principles. Since Myanmar is moving towards democracy and is committed to peace it is imperative that the country reverse its ambitious homogeneity in favour of its officially natural 135 ethnic and religious heterogeneity. In this regard a number of initiatives are important. First, Myanmar's civilian leader, Aung Sun Suu Kyi, is a globally recognized respected leader considered as a symbol and icon of democratic rights and democracy in the country. Since she is part of the government and a highly instrumental figure in democratic transition, she has a particular role to play favour of multi-ethnic and multiculturalism. She can take the nation going beyond the narrow state narrative of pure Burmese nationalism. Second, the international community has a particular role to play as human rights and democratic principles are universal. Like the practice earlier foreign major powers and international organizations such as the United Nations, Human Rights Watch, and the International Criminal Court can keep Myanmar under pressure of legal implications in cases of violation of human rights and democratic norms. Third, ASEAN can rethink its traditional non-interference policy and remodel its operating framework along with international human rights regimes and democratic principles. In the face of gross violation of human rights of millions of people in a next-door country, ASEAN's silence and turning of a blind eye can only make it morally complicit to the crime. South Asian and South-East Asian nations are naturally heterogeneous in terms of ethnicity, religion, language, and culture. A denial of such reality or intervention into such natural intermix in an attempt to create an artificial manufactured new social and political structure can trigger widespread conflict and tension and be irreparably fatal for peace.

\section{Notes}

1 U Ko Ni was the son of Sultan Mahmud, who was one of three Rohingya representatives in Burma's legislative assembly.

2 A version of this sub-section appeared in E-International Relations. See Farzana (2018).

\section{References}

Abrar, Choudhury. 1994. "Repatriation of Rohingya Refugees." Forced Migration. https:// bit.ly/2I8dBjb. Accessed July 15, 2018.

Ahmen, Ishtiaq. 2005. The Politics of Group Rights: The State and Multiculturalism. New York: Oxford University Press.

Alsaafin, Linah. 2018. "For How Long? Displaced Rohingya Lament Life in No-Man's Land." Al Jazeera News, August 4. https://bit.ly/2ngQdHQ. Accessed August 8, 2018.

Amnesty International. 2018. "Myanmar Militarizing Rohingya Villages." The Daily Star, March 13. https://bit.ly/2LTBcdG. Accessed July 18, 2018.

Banerjee, Sreeparna. 2019. "The Rohingya Crisis: A Health Situation Analysis of Refugee Camps in Bangladesh.” ORF Special Report No. 91, July. Observer Research Foundation.

The Bangkok Post. 2017. "Malaysian PM's Demands Meet with Yangon Protests." March 13. https://www.bangkokpost.com/world/1151629/malaysian-pms-demandsmeet-with-yangon-protests. Accessed April 4, 2020. 
Beets, Benjamin H. 2015. The Political Influence of the Military before and after Democratic Transition: Experiences from Indonesia - An Assessment on Myanmar. MA Thesis, Victoria University of Wellington.

Bennett, James. 2017. "Rohingya Crisis: Rape Victims Face Shame and Ongoing Trauma as They Plead for Justice." Australian Broadcasting Corporation (ABC). https://bit. ly/2ODfcBE. Accessed August 2, 2018.

Bhattacharya, Bisvesuar. 1927. "Bengali Influence in Arakan, Bengal Past and Present." Journal of the Calcutta Historical Society 33:139-144.

Blackburn, Terence R. 2000. The British Humiliation of Burma. Bangkok: Orchid.

Buchanan, Francis. 1799. "A Comparative Vocabulary of Some of the Languages Spoken in the Burma Empire." Asiatic Research 5: 219-240. Republished in the SBBR. SOAS Bulletin of Burma Research 1, no. 1 (Spring 2003): 40-57.

Bünte, Marco. 2014. "Burma's Transition to Quasi-Military Rule: From Rulers to Guardians?" Armed Forces \& Society 40(4): 742-762.

Chang, Iris. 1997. The Rape of Nanking: The Forgotten Holocaust of World War II. New York: Basic Books.

Charney, Michael. 2016. "Arakan or Rakhine in Myanmar since the 14th Century: From Inclusion to Polarisation and Exclusion." Paper presented at the Research Conference on Myanmar's Democratic Transition and the Persecuted Rohingya, May 11, 2016, The South Asia Research Cluster, Oxford University, Oxford.

El-Aswad, El-Sayed. 2013. "Images of Muslims in Western Scholarship and Media after 9/11.” Domes: Digest of Middle East Studies 22(1): 39-56.

Farzana, Kazi Fahmida. 2017. Memories of Burmese Rohingya Refugees: Contested Identity and Belonging. New York: Palgrave Macmillan.

Farzana, Kazi Fahmida. 2018. "Nationalism, Persecution and Repatriation of the Rohingya." E-International Relations, April 5. https://bit.ly/2ABMQoE. Accessed July 31, 2018.

Fortify Rights. 2014. “I Thought They Would Kill Me': Ending Wartime Torture in Northern Myanmar." Fortify Rights, June. https://bit.ly/1lhdaDW. Accessed August 8, 2018.

Hancock, Stephanie. 2017. “'The Darkness of Humans': Investigating Mass Rape in Burma. Human Rights Watch.” November 16.

Harvey, Godfrey E. 1967. History of Burma: From the Earliest Times to 10 March 1824: The Beginning of the English Conquest. London: Frank Cass.

Hindustan Times. 2017. "Rohingya Women Forced into Human Trafficking: Aid Agencies." April 5. https://bit.ly/2KqJZyh. Accessed August 4, 2018.

Hirschauer, Sabine. 2014. The Securitization of Rape: Women, War and Sexual Violence. New York: Palgrave Macmillan.

Holt, John Clifford. 2019. Myanmar's Buddhist-Muslim Crisis: Rohingya, Arakanese, and Burmese Narratives of Siege and Fear. Honolulu: The University of Hawaii Press.

Human Rights Watch. 2015. "Thailand: Mass Graves of Rohingya Found in Trafficking Camp.” May 1. https://bit.ly/1VoaRjO. Accessed August 4, 2018.

Ibrahim, Azeem. 2016. The Rohingyas: Inside Myanmar's Hidden Genocide. London: Hurst \& Company Publishers Ltd.

Jackson, Richard. 2007. “Constructing Enemies: 'Islamic Terrorism' in Political and Academic Discourse." Government and Opposition 42(3): 394-426.

Jilani, Ahmed F. 1999. The Rohingyas of Arakan: Their Quest for Justice. Dhaka, Bangladesh: The University Press.

Kamal, Zoglul. 2017. "The Untapped Wealth of Rakhine and the Persecution of the Rohingya." Dhaka Tribune, September 26. 


\section{Kazi Fahmida Farzana}

Klug, Foster. 2018. "Rohingya Say Myanmar Targeted the Educated in Genocide." The Independent, June 5. https://ind.pn/2ObhCXc. Accessed August 4, 2018.

Kymlicka, Will. 2005. "Liberal Multiculturalism: Western Models, Global Trends, and Asian Deblates." In Will Kymlicka and He Baogang (eds), Multiculturalism in Asia (pp. 22-55). Oxford: Oxford University Press.

Kymlicka, Will. 1995. Multicultural Citizenship: A Liberal Theory of Minority Rights. Oxford: Clarendon Press.

Marshall, Thomas Humphrey. 1965. Claims, Citizenship and Social Development. New York: Anchor.

Menon, Praveen. 2015. "Malaysia Finds 139 Graves in 'Cruel' Jungle Trafficking Camps." Reuters, May 25. https://reut.rs/2vgOqqD. Accessed August 4, 2018.

Moscotti, Albert D. 1977. Burma's Constitution and Elections of 1974. Singapore: Institute of Southeast Asian Studies.

Myint, Moe. 2019. "5 Civilians Killed as Tatmadaw Troops Open Fire on Village in N. Rakhain: Witnesses." March 22. www.irrawaddy.com. Accessed September 30, 2020.

Naidu, Shumisha. 2017. "UMNO Leads KL Protest against Persecution of Rohingyas." Channel News Asia, September 6. https://www.channelnewsasia.com/news/asia/umnoleads-kl-protest-against-persecution-of-rohingyas-9197660. Accessed April 4, 2020.

Peng, Nian. 2019. "Budding Indo-Myanmar Relations: Rising but Limited Challenges for China." Asian Affairs 50(4): 588-601.

Phayre, Arthur P. 1967. History of Burma: Including Burma Proper, Pegu, Taungu,Tenasserim, and Arakan. London: Susil Gupta.

Quadir, Serajul. 2017. "U.N. Official Says Will Raise Sexual Violence against Rohingya with ICC.” Reuters, November 12.

Ranjan, Amit. 2017. "The Rohingya Crisis - A Challenge for India and Bangladesh." ISAS Working Paper No. 271. Institute of South Asian Studies, National University of Singapore.

Reuters. 2017. "Myanmar, Bangladesh Sign Rohingya Return Deal: Myanmar Official." November 23. https://reut.rs/2mXK326. Accessed August 2, 2018.

Selth, Andrew. 2018. Myanmar's Armed Forces and the Rohingya Crisis. Washington, DC: United States Institute of Peace.

Skjelsbæk, Inger. 2011. The Political Psychology of War Rape: Studies from Bosnia and Herzegovina. New York: Routledge.

Smith, Martin. 1999. Burma: Insurgency and the Politics of Ethnicity. London: Zed Books.

Solanki, Viraj. 2018. "India Boosts Relations with Myanmar, Where Chinese Influence Is Growing." https://www.iiss.org/blogs/analysis/2018/05/india-myanmar-china-relations. Accessed April 4, 2020.

Stokke, Kristian, Roman Vakulchuk and Indra Øverland. 2018. "Myanmar: A Political Economy Analysis." Research Report. Oslo: Norwegian Institute of International Affairs. https://bit.ly/2wMvkK9. Accessed August 4, 2018.

Tanaka, Yuki. 2001. Japan's Comfort Women. New York: Routledge.

UN Children's Fund. 2017. "Bangladesh: Humanitarian Situation Report.” Report No. 14 (Rohingya Influx). https://bit.ly/2IZbdN5. Accessed August 4, 2018.

UN News. 2017. "UN Human Rights Chief Points to 'Textbook Example of Ethnic Cleansing' in Myanmar." September 11. https://bit.ly/2sRdqCQ. Accessed August 8, 2018.

United Nations High Commissioner for Refugees. 2018 "UNHCR Operational Update Bangladesh 19-31 July 2018.” https://bit.ly/2OQiLo9. Accessed August 8, 2018.

Yi, Beh Lih. 2015. "Malaysia Migrant Mass Graves: Police Reveal 139 Sites, Some with Multiple Corpses." The Guardian, May 25. 
Young, Iris Marion. 1989. "Polity and Group Differencer: A Critique of the Ideal of Universal Citizenship." Ethics 99(2): 250-274.

Young, Iris Marion. 1990. Justice and the Politics of Difference. Princeton, NJ: Princeton University Press.

Zarni, Maung. 2017. "Myanmar's Slow Burning Genocide of the Rohingya People." Joukowsky Forum, the Watson Institute for International and Public Affairs, Brown University, November 20.

Zhao, Hong. 2008. "CHINA and India: Competing for Good Relations with Myanmar." The Journal of East Asian Affairs 22, no. 1 (Spring/Summer): 175-194.

Zhou, Naaman and Michael Safi. 2017. "Desmond Tutu Condemns Aung San Suu Kyi: 'Silence Is Too High a Price'., The Guardian, September 8. 